\title{
PARADOKS PEREMPUAN MINANG DI RANAH POLITIK
}

\author{
Selinaswati \\ Universitas Negeri Padang
}

\begin{abstract}
Abstrak
Tulisan ini mengkaji politisi perempuan di Sumatera Barat. Daerah yang memiliki ciri khas tersendiri dalam konteks adat dengan sistem matrilinial. Dengan asumsi sistem matrilinial memberi peluang dan kesempatan yang lebih bagi perempuan untuk berkiprah di sektor publik, seperti ranah politik, mestinya cukup banyak perempuan yang memperoleh kursi diparlemen. Tetapi fakta menunjukkan jumlah dan persentase politisi perempuan di DPRD, baik provinsi, kabupaten dan kota tidak menunjukkan angka yang signifikan. Penelitian dilakukan dengan pendekatan kualitatif dan metode pengumpulan data observasi dan wawancara mendalam kepada 17 informan. Hal itu dilakukan untuk mengetahui penyebab dan pengaruh minimnya politisi perempuan di lembaga perwakilan rakyat. Hasil penelitian menunjukkan terdapat dualisme sistem: matrilineal dan patriarkal Islam yang mempengaruhi mindset para informan. Ini berpengaruh pada perempuan untuk berkiprah di ranah publik, seperti politik dimana perempuan yang berada di panggung politik tak lepas dari pandangan standar ganda laki-laki. Paradoks ini juga tampak pada peran dan dukungan kerabat laki-laki (yang memiliki status ketokohan, baik di tengah masyarakat atau dalam keluarga besarnya) agar politisi perempuan berhasil menjadi anggota Dewan.
\end{abstract}

\section{Kata Kunci: Politisi Perempuan; Politik; Keterwakilan Perempuan}

\section{Abstract}

This paper examines female politicians in West Sumatra. The place with unique matrilineal system existed since long time ago. Assuming that the matrilineal system gave opportunity toward women in this area to involve in public space legitimately, the number of female representative in local parliament must increase effectively. By using qualitative method with case study research, indepth interview have been done toward 17 informants. The result showed that the dualism idea of matrilineal and patriarchy of Islamic teaching are influence of these male and female informants. This condition affected women when they involve in public space including in political arena. In this study, the paradox occurred in which women political participation cannot separate from the important roles of their male connection. That male family connection such as public figure, (even formal leader such as Datuk) have highly contributions for female politicians to have a seat in the local parliament.

\section{Keywords: Famale Politicians; Politics; Woman's Reprecentation}

\section{Pendahuluan}

Kajian tentang politisi perempuan telah menarik minat banyak peneliti. Berbagai aspek yang terkait dengan politisi perempuan sudah banyak ditulis dan dibaca laporan hasil penelitiannya; seperti tindakan afirmatif atau kuota $30 \%$, partisipasi politik perempuan sebagai Calon dan Anggota Legislatif (Caleg dan 
Aleg) di parlemen, rekrutmen politisi perempuan, pemberdayaan politisi perempuan dan eksistensi perempuan di partai politik serta peluang yang diberikan partai politik bagi politisi perempuan.Semua bentuk penelitian tersebut substansinya adalahmengkritisi partisipasi politik perempuan, khususnya terkait dengan keberadaan, jumlah dan komposisi perempuan di lembaga perwakilan di tingkat nasional ataupun lokal.

Berbagai upaya telah dilakukan dalam meningkatkan keterwakilan perempuan di lembaga rakyat, baik usaha lembaga resmi pemerintah, non pemerintah, kelompok perempuan aktivis, pemerhati masalah perempuan dan kalangan akademisi melalui penelitian pada pusat studi mereka masing-masing.
Semua kegiatan di berbagaielemen masyarakat tersebut pada hakikatnya memiliki tujuan yang sama, agar partisipasi politik perempuan mengalami peningkatan. Peningkatan keterwakilan tersebut, tentunya tak sekedar di lembaga rakyat level nasional seperti DPR RI dan DPD, tapi juga diharapkan akan berpengaruh pada persentase keberadaan politisi perempuan di DPRD provinsi, kabupaten dan kota.

Namun tampaknya jumlah perempuan politisi yang berhasil menjadi wakil rakyat tersebut masih belum menunjukkan angka yang signifikan. Untuk perwakilan DPR di tingkat pusat misalnya, dapat dilihat dari tabel data Komisi Pemilihan Umum (KPU) di bawah ini:

Tabel 1. Keterwakilan Perempuan di DPR RI selama 3 Periode Pemilu

\begin{tabular}{|l|c|c|c|c|c|}
\hline No & \multirow{2}{*}{$\begin{array}{c}\text { Periode } \\
\text { Pemilu }\end{array}$} & \multicolumn{2}{|c|}{ Jumlah Aleg } & \multicolumn{2}{c|}{ Persentase } \\
\cline { 3 - 6 } & & Perempuan & Laki-laki & Perempuan & Laki-laki \\
\hline 1 & $2004-2009$ & 61 & 489 & 11,09 & 88,90 \\
\hline 2 & $2009-2014$ & 110 & 450 & 19.65 & 80.35 \\
\hline 3 & $2014-2019$ & 97 & 463 & 17,32 & 82,68 \\
\hline
\end{tabular}

Sumber : Data KPU 2014 (tabulasi oleh peneliti)

Dari tabel 1 dapat diketahui bahwa fluktuasi keterwakilan perempuan di parlemen nasional nyata adanya. Adanya peningkatan di satu periode namun periode berikutnya terjadi penyusutan jumlah politisi perempuan menunjukkan masih belum stabilnya keberadaan politisi perempuan di tingkat nasional. Kondisi yang hampir sama juga tampak pada jumlah politisi perempuan di tingkat lokal, jumlah keterwakilan perempuan di DPRD Provinsi, kabupaten dan kota ratarata berkisar dibawah 10 bahkan tak

Jurnal Socius Vol. 3, No.1, Th. 2016

ISSN: 2356-4180 jarang berada dalam hitungan sebelah jari. Untuk 33 provinsi di Indonesia, data dari Puskapol UI mengungkapkan bahwa pada Pemilu periode 2014-2019, terdapat sebanyak 335 Anggota Legislatif (Aleg) perempuan dari total 2.114 Aleg atau sekitar $15.85 \%{ }^{1}$. Jumlah ini masih jauh dari target ideal $30 \%$ perempuan di

1 ------- Profil Anggota DPR dan DPD RI 20142019, Pusat Kajian Politik Departemen IlmuPolitik FISIP Universitas Indonesia 26 September 2016 
parlemen seperti yang telah diupayakan melalui tindakan afirmatif kuota $30 \%$.

Dari 33 provinsi tersebut, hanya satu DPRD Provinsi yaitu Sulawesi Utara yang memenuhi kuota dengan jumlah Aleg perempuannya 14 dari total 45 Aleg atau $31.11 \%$. Selebihnya berkisar antara $2.22 \%$ (Provinsi Papua Barat) sampai 27,69\% (Provinsi Riau). Sedangkan untuk Sumatera Barat, justru mengalami tren penurunan dibanding periode sebelumya (2009-2014).

Jumlah Aleg perempuan di DPRD Provinsi Provinsi Sumatera Barat, seperti tampakpada tabel 2 berikut ini:

Tabel 2. Keterwakilan Perempuan di DPRD Sumbar selama 3 Periode Pemilu

\begin{tabular}{|c|c|c|c|c|c|}
\hline \multirow{2}{*}{ No } & \multirow{2}{*}{$\begin{array}{c}\text { Periode } \\
\text { Pemilu }\end{array}$} & $\begin{array}{c}\text { Pumlah } \\
\text { puan }\end{array}$ & $\begin{array}{c}\text { Laki- } \\
\text { laki }\end{array}$ & $\begin{array}{c}\text { Perem } \\
\text { puan }\end{array}$ & $\begin{array}{c}\text { Laki- } \\
\text { laki }\end{array}$ \\
\hline 1 & $\begin{array}{l}2004- \\
2009\end{array}$ & 5 & 50 & 9,09 & 90,91 \\
\hline 2 & $\begin{array}{l}2009- \\
2014\end{array}$ & 7 & 55 & 12,72 & 87,28 \\
\hline 3 & $\begin{array}{l}2014- \\
2019\end{array}$ & 6 & 65 & 9,23 & 90,77 \\
\hline
\end{tabular}

Sumber : KPU Sumbar (tabulasi oleh peneliti)

Dari tabel tampak jelas fluktuasi jumlah anggota DPRD perempuan, meski ada kenaikan 3\% pada periode 2009-2014 dibanding periode 2004-2009, namun kembali persentasenya menurun menjadi $9,23 \%$ dengan jumlah aleg perempuan sebanyak 6 orang dari total 65 anggota dewan. Ketidakstabilan keberadaan perempuan politisi di parlemen ternyata dijumpai di DPRD Sumbar dan masih jauh dari target kuota $30 \%$.

Menjadi menarik untuk mengkaji politisi perempuan di Sumatera Barat bila dikaitkan dengan akar tradisi masyarakat SumateraBarat yang dominan bersuku Minang dan terkenal dengan sistem adat matrilinealnya. Sistem matrilinial dipercaya memberikan peluang bagi kaum

Jurnal Socius Vol. 3, No.1, Th. 2016 ISSN: 2356-4180 perempuannya untuk turut serta dalam pengambilan keputusan bagi orang banyak dikaumnya; dalam hal ini keluarga luas yang satu suku dengan perempuan tersebut. Ini menunjukkan bahwa perempuan berkiprah tak hanya di sekitar sektor domestik semata. Mereka diberi peluang dan kesempatan untuk berkegiatan di ranah publik. Kondisi demikian sudah terlihat dari sejak dahulunya, seperti tampak bermunculannya tokoh politik, pendidikan dan pejuang perempuan.

Secara historis sejak zaman kolonial dijumpai sejumlah perempuan minang yang berkiprah di luar ranah domestik. Bahkan dari segi jumlah, variasi kegiatan perempuan di sektor publik tersebut melebihi kiprah perempuan dari daerah lainnya pada periode yang sama.Seperti Rahmah El Yunusiah ${ }^{2}$ membina dan mengembangkan Lembaga Pendidikan Diniyah Putri, yang hingga saat sekarang pun masihjalan. Rasuna Said sebagai aktifis politik, terkenal sebagai orator ulung yang membangkitkan semangat pendengarnya melawan penjajah. Demikian pula dengan Sitti Manggopoh ${ }^{3}$ perempuan pemberani yang memimpin para pejuang (yang semuanya laki-laki) melawan Penjajah Belanda dari wilayah mereka di Pariaman dan terkenal dengan Perang Belasting. Setelah itu Rohana Koeddoes $^{4}$, wartawati pertama perempuan di Indonesia yang bersama-sama dengan teman jurnalis perempuan lainnya menyuarakan hak dan kepentingan

${ }^{2}$ Elsbeth Locher-Scholten \& Anke Niehof (edited), 1992. 'The life of Rangkayo Rahmah El Yunusiya', in Indonesian Women in Focus, Leiden: KITLV Press, hal: 54

3 Nita Arifin \& Abeltasman, 2003. Sitti Manggopoh; Perempuan Minang itu Layak Diberi Gelar Pahlawan, Padang: Citra Budaya

${ }^{4}$ Fitriyanti, 2000. Roehanna Koeddoes. Perempuan Sumatera Barat, Jakarta: Yayasan Jurnal Perempuan 


\section{Paradoks Perempuan Minang ...}

perempuan melalui surat kabar 'Soentiang Melayu' yang mereka miliki dan kelola sendiri.

Bahwa perempuan Minang yang terbiasa dengan sistem matrilinial dengan pola kepemimpinan yang demokratis dan egaliter, sedikit banyak ini memberi pengaruh berupa pemberian kesempatan dan peluang untuk berkiprah di sektor publik, termasuk juga berkiprah di bidang politik. Dengan asums semestinya keterwakilan perempuan di ranah politik dalam hal ini sebagai Aleg cukup memadai. Namun fakta berdasar data menunjukkan tidak signifikannya jumlah perempuan di parlemen dengan sistem yang memberikan dukungan ke perempuan untuk berkiprah di sektor publik. Untuk itu artikel ini berusaha mengungkapkan bagaimana peran lingkungan sosial budaya dan masyarakat setempat dalam hal ini konteks budaya matrilinial suku Minangkabau mendorong perempuan berpartisipasi dalam politik. Selain itu juga menjelaskan penyebab minimya keterwakilan perempuan di Sumatera Barat dalam perolehan kursi di lembaga perwakilan tingkat provinsi, kabupaten dan kota.

\section{Metode Penelitian}

Pendekatan dalam penelitian ini adalah kualitatif dengan tipe studi kasus, lebih tepatnya studi kasus intrinsik. Penerapan studi kasus intrinsik ini dengan pertimbangan penelitian yang telah dilakukan adalah mengkaji, menginterpretasikan secara detail suatu kasus dalam situasi apa adanya yang natural. Konteks natural yang dimaksud adalah sistem matrilinial. Sehingga diperoleh gambaran yang menyeluruh, mendalam tentang keterwakilan perempuan di lembaga perwakilan di Sumatera Barat yang memiliki tradisi budaya matrilinial.

Jurnae Socius Vol. 3, No.1, Th. 2016

ISSN: 2356-4180 $\begin{array}{rlr}\text { Data } & \text { dikumpulkan } & \begin{array}{c}\text { dengan } \\ \text { melakukan } \\ \text { wawancara }\end{array}\end{array}$ terhadap lima orang Aleg periode 20042009, satu Caleg gagal periode 2009-2014 dan satu Aleg inkumben periode 20092014. Lalu lima orang tokoh masyarakat yang masing-masing terdiri dari wali nagari, akademisi, tokoh adat, tokoh agama dan tokoh adat perempuan (Bundo Kanduang). Selanjutnya juga lima orang laki-laki yang berasal dari Sumatera Barat bersuku Minang dimintai tanggapan terkait dengan perempuan aktif di luar rumah.Total informan berjumlah 17 orang.

\section{Sistem Matrilinial dan Dominasi Perempuan}

Beberapa studi tentang sistem matrilineal pada masyarakat etnis Minangkabau, seperti Pegy R Sanday, Evelyn Blackwood, Tsuyoshi Kato, Joselin d Young, Cora d Stueers Vreede mengungkapkan adanya pandangan yang menempatkan posisi dan peran perempuan cukup istimewa ${ }^{5}$. Bahwa harta pusaka milik satu suku atau kaum di wilayah ini diwariskan melalui garis keturunan ibu dan otomatis berada dalam kendali kaum perempuan di satu suku. Laki-laki dalam kaum tersebut, hanya memiliki hak sebatas mengolah dan memanfaatkan lahan tanah komunal tersebut.Sedangkan aturan apakah tanah komunaldigilir pengelolaanya, siapa yang mengolah lahan tertentu dari harta komunal itu biasanya berdasarkan musyawarah wakil anggota kaum di satu Rumah Gadang. Lalu keputusan akhir, kata iya atau tidak

\footnotetext{
${ }^{5}$ Lihat Peggy R Sanday, 2002, Women at the Centre, Life in a Modern Matriarchy Ithaca: Cornel University Press, hal: 65
} 
lahan boleh dikelola oleh si A atau si $\mathrm{B}^{6}$, laki-laki dari anggota kaum ditentukan oleh perempuan yang dituakan dalam kaum tersebut yang biasanya disebut dengan Bundo Kanduang.

Selanjutnya, Wieringa juga berpendapat bahwa selain sistem matrilinial, sikap egaliter yang sudah berlaku lama dalam konteks budaya etnis Minangkabau memberikan nilai lebih pada status perempuan ${ }^{7}$. Kondisi yang demikian dinilai membawa dampak positif pada kaum perempuannya ketika beraktifitas di ranah publik.Bahwa sistem matrilineal dan pola kepemimpinan egaliter; hal ini tergambar dalam konsep falsafah pemimpin ditinggikan sarantiang dan didahulukan selangkah. Konsep kepemimpinan yang egaliter ini juga memberikan kesempatan dan peluang kepada kaum perempuan di Minangkabau untuk menyalurkan suranya langsung ke level pimpinan dengan menempatkan perempuan sebagai wakil kaum mereka yang disebut dengan Bundo Kanduang. Seiring dengan asumsi perempuan di masyarakat matrilinial, anggapan yang kontradiktif terhadap peran perempuan yang hidup pada masyarakat yang mendasarkan garis keturunan dari bapak (patrilinial). Di mana penentuan kekuasaan berada pada pihak laki-laki (patriarchat). Perempuan dengan segala aspek kehidupan dalam masyarakat yang didominasi kaum laki-laki (patriarki) ini berada pada posisi subordinat, dinomorduakan dalam sejumlah aspek kehidupan seperti bidang ekonomi bahkan politik. Di bidang ekonomi misalnya,

\footnotetext{
6 Wawancara dengan Ketua Bundo KanduangSumatera Barat Puti Reno Raudha Thaib, 12 September 2012

${ }^{7}$ Saskia Wieringa, 1995, Subversive Women, New Delhi, India: Raj Press, hal: 212
}

Jurnal Socius Vol. 3, No.1, Th. 2016 ISSN: 2356-4180 meski bahkan hampir dalam semua aspek kehidupan, relasi perempuan dan laki-laki pada masyarakat dengan budaya patriarki memposisikan perempuan sebagai yang terpinggirkan, yang berimplikasi pada berbagai macam ketakadilan, diskriminasi dan subordinasi perempuan di berbagai lini kehidupan, seperti politik, ekonomi, pendidikan, budaya dan abahkan agama.

\section{Dualisme Sistem di Masyarakat Minang}

Sebenarnyalah terlihat ada semacam paradoks bahwa etnis Minangkabau dengan sistem matrilinealnya tak seperti yang dipersepsikan masyarakat selama ini. Sistem matrilineal hanya sedikit memberi kontribusi pada kiprah perempuan di ranah publik, semisal partisipasi politik. Karena pada dasarnya masyarakat Minangkabau hidup dalam dualisme sistem, tak murni matrilineal sepenuhnya, tapi percaya sekaligus mempraktekkan sistem patriarkal yang didasarkan kepada ajaran agama Islam. Bahwa Islam sudah menjadi identitas bagi etnis Minangkabau dapat dibuktikan dengan pernyataan dari kalangan orang Minang sendiri dengan pernyataan bukanlah seseorang itu dianggap orang Minang, bila ia tak memeluk agama Islam. Jauh sebelum Islam masuk ke Indonesia dan Sumatra Barat khususnya pada abad ke 16, etnis Minangkabau sudah memakai sistem matrilineal ${ }^{8}$. Meski sempat terjadi konflik antara ajaran Islam yang dibawa oleh kaum ulama (wahabbi) dari tanah Arab dengan budaya Matrilinial, hingga puncaknya pada perang Padri pada tahun 1821-1837. Namun konflik itu tak lama, kedua sistem ini bisa berekonsiliasi hingga keduanya bisa seiring sejalan seperti yang tergambar

${ }^{8}$ Christine E. Dobbin, 1992, Kebangkatan Islam dalam ekonomi petani yang sedang berubah Sumatra Tengah, Jakarta: ININ, hal: 23 
dalam falsafah etnis minang; 'adat basandi syarak, syarak basandi kitabullah'.

Bukti lain, tampak pada pembagian harta warisan yang cukup adil, dijumpai ketika terjadi kombinasi pewarisan berdasar adat budaya dan ajaran Islam. Bila itu harta pusaka tinggi, diwariskan kepada kaum keluarga perempuan. Sementara harta pusaka rendah, pencarian dari kepala keluarga diwariskan kepada anak-anak dalam keluarga inti, didasarkan kepada hukum Islam.

Harta yang disebut pusaka tinggi semisal tanah, rumah gadang dan sawah ladang berada dalam genggaman perempuan yang dituakan dalam sukunya itu. Meski harta milik bersama, namun penentuan giliran siapa mengolah tanah yang mana, siapa yang mendapat bagian berapa dari hasil panen sawah pusaka, diatur sedemikian rupa oleh perempuan. Bagaimana perempuan diposisikan dalam masyarakat Minang tampak dalam beberapa ungkapan seperti Umbun Puruik, pegangan kunci bahwa perempuan penggengam harta

Tampak nyata dualisme yang saling mengisi antara budaya matrilineal sebagai budaya asli etnis Minangkabau dengan budaya Patriarkal yang merupakan ajaran dari agama Islam. Kombinasi antara penerapan sistem matrilineal yang didasarkan pada budaya asli Masyarakat Minang dan ajaran agama Islam yang dipeluk lebih dari $98 \%$ masyarakatnya ${ }^{9}$, sepertinya berdampak pada sikap dan prilaku masyarakatnya terhadap perempuan.

Terdapat semacam standar ganda bagaimana laki-laki Minang menyikapi keinginan perempuan berkiprah di ranah publik. Dari hasil wawancara terungkap

\footnotetext{
9 ------------- SumateraBarat dalam Angka, 2012, Biro Pusat Statistik.Padang : BPS
}

Jurnae Socius Vol. 3, No.1, Th. 2016 bahwa perempuan Minang boleh saja aktif di luar rumah, menjadi pendidik, pengusaha atau politikus, tapi jangan lupa dengan tugas utama sebagai istri, ibu dan penanggung jawab urusan rumah tangga.

Pernyataan demikian diungkapkan dalam wawancara dengan laki-laki minang sebagai informan dalam penelitian ini. Bahkan ada yang menganggap bahwa tugas domestik itu sebagai kodrat perempuan. Amatlah disayangkan bahwa konsep jender dan kodrat sendiri bagi kebanyakan mereka masih rancu. Kodrat sebagai sesuatu yang melekat pada tubuh manusia, merupakan pemberian Tuhan yang tak bisa dipertukarkan, sedangkan pekerjaan di sektor domestik seperti mencuci, merawat anak dan mengatur rumah tangga bukan kodrat ${ }^{10}$ Pemahaman yang berbeda soal mana yang kodrat mana yang tidak oleh kebanyakan laki-laki minang tampaknya ikut dipengaruhi atau didasarkan beberapa ayat Al qur'an dan hadis yang bias interpretasi dan memojokkan posisi perempuan. Karena kodrat perempuan adalah melahirkan, berimplikasi pada aktifitas mereka di sektor public, yakni munculnya beban ganda karena tanggung jawab domestik cendrung sepeuhnya dilakukan pihak perempuan.

Ditambah lagi, perempuan itu sendiri juga merasa ada yang kurang bila mereka tidak menyelesaikan dulu tugas domestik sebelum melakukan tugas lain di luar rumah. Maka ternyata dualisme pemikiran demikian tak hanya dimiliki laki-laki namun juga oleh kaum perempuannya. Ini bisa dimaklumi karena mereka sedari kecil sudah mengalami proses sosialisasi dan internalisasi nilai bahwa tanggung jawab sebagai perempuan cendrung di arena domestik.

\footnotetext{
${ }^{10}$ Mansour Fakih, 1996. Analisa Gender dan Transformasi Sosial. Yogyakarta: Pustaka Pelajar
} 
Kepercayaan bahwa pembagian kerja yang mewajibkan perempuan mengurus urusan domestik sepertinya memang sudah berurat berakar ribuan tahun lamanya, seperti diuraikan Friedrich Engles dalam buku yang diterbitkan tahun 1884, The Origin of Family, Private Property and the State ${ }^{11}$.

Engels menjelaskan sesungguhnya awal mula peradaban manusia, yang ketika itu disebut zaman liar (savagery) dan zaman pengumpul, menerapkan sistem egaliter antara laki-laki dan perempuan. Relasi laki-laki dan perempuan diwarnai dengan saling kerjasama, hidup bersama dan secara seksual bersifat permisif. Dengan kata lain, seseorang bebas berganti pasangan dengan siapa saja tanpa ada dominasi satu jenis kelamin (laki-laki) atas jenis kelamin lainnya (perempuan) seperti kebanyakan fenomena sekarang ini.

Dalam perjalanannya, setelah mereka mengenal ilmu bercocok tanam, bertani dan lahan pertanian, manusia beroirientasi kepada yang namanya pengumpulan harta benda, berupa lahan pertanian, rumah dan barang perlengkapan bercocok tanam lainnya. Di era yang telah mengenal harta itu, lakilaki terkendala dalam mewariskan harta kepada anak keturunannya karena tidak diketahui siapa anak sah yang berasal dari benihnya. Ini disebabkan kehidupan yang tak mengenal norma perkawinan atau hidup permisif itu tadi. Maka jalan satusatunya adalah menetapkan status anak dari garis keturunan ibu, karena anak mengetahui persis siapa ibu, tapi tidak bapaknya. Dengan demikian matrilineal mulai terbentuk.

\footnotetext{
${ }^{11}$ Arif Budiman, 1985. Pembagian Kerja Secara Seksual Sebuah Pemahaman Sosiologis terhadap Peranan Wanita di Masyarakat, Jakarta: Gramedia.
}

Jurnae Socius Vol. 3, No.1, Th. 2016
Bersamaan dengan adanya kebutuhan akan memiliki anak yang sah dari pasangan yang jelas ibu bapaknya, telah mendorong terbentuknya sistem perkawinan yang kemudian berbentuk institusi disebut keluarga (family). Dalam masa ini, awalnya yang mengatur perempuan bersuamikan siapa ditentukan oleh ibunya si perempuan, maka dengan demikian pengambilan keputusan oleh perempuan telah ada ketika itu, ini mengesankan adanya sistem matriarkat juga eksis.

Tingginya keinginan atas pengumpulan dan kepemilikan harta benda mulai didominasi laki-laki dan mendorong mereka untuk menerapkan sistem perkawinan monogamy bagi perempuan, namun tidak kepada laki-laki. Paksaan monogamy bagi perempuan dimaksudkan untuk menjaga kemurnian darah sebuah keturunan, hingga kekayaan pribadi dapat diwariskan menurut garis keturunan keluarga. Hanya saja, sejalan dengan itu perempuan otomatis ditempatkan di rumah, didomestifikasi dengan tameng sebagai pelanjut keturunan dan pemelihara anak-anak generasi baru. Ini menyebabkan perempuan terlepas dari sumber-sumber akses ekonomi, politik dan kekuasaan, maka saat itu dimulailah sistem patriarchal (dominasi laki-laki atas perempuan dalam segala aspek kehidupan). Oleh Engels ini disebut sebagai 'kekalahan terbesar perempuan dalam sejarah umat manusia' ${ }^{12}$. Hingga sekarang ini, hampir di semua belahan dunia menerapkan sistem patriarchal, hanya sebagian kecil etnis yang menganut sistem parental. Bahkan dari kajian para Antropolog, ditemukan tak lebih dari 10 etnis di dunia yang menganut sistem matrilineal, seperti (Sumatera Barat,

${ }^{12}$ Ibid, hal: 22 
Indonesia), Bhutan, Campa (Vietnam), Muangthai (segitiga emas Thailand), beberapa suku bangsa kecil di kawasan Asia Selatan (India), Afrika, dan Badui (Timur tengah).

Kembali ke konteks adat dan budaya, perempuan Minangkabau dengan sistem matrilineal memberi peluang kepada perempuan dalam umnya sebagai pemimpin. Seperti konsep Bundo Kanduangyang didalam tatanan adat Minangkabau sebagai salah satu unsur kelengkapan adat. Penggambaran Bundo Kanduangsebagai perempuan yang dituakan di dalam kaum yang mengatur segala urusan di rumah gadang (umbun puruk pegangan kunci), perempuan minang sebagai tempat bertanya dan memberi nasehat (umbun puruak aluang bunian). Sebagai sentral segala system (pusek jalo kumpulan tali).

Ungkapan yang memberikan inspirasi bahwa perempuan minang sebagai sentral dari kehidupan masyarakat dalam konteks budaya ternyata tidak tampak pengaruh yang signifikan dengan situasi perempuan kini. Dari kondisi riil, realita yang ada menunjukkan bahwa matrilineal yang diharapkan mendorong perempuan Minang untuk lebih bisa mengaktualisasikan diri di ruang publik dan mendapatkan kesempatan yang sama di bidang politik sepertinya perlu dikaji ulang.

Beberapa kasus terkait keberadaan perempuan di parlemen misalnya, ternyata tak lepas dari peran kerabat lakilaki si perempuan itu sendiri. Apakah sebagai suami, kakak, kakak ipar atau paman (atau mamak dalam istilah Minang). Dari wawancara dengan Aleg perempuan di DPRD Provinsi Sumatra Barat periode 2004-2009, terungkap tiga diantara lima Aleg tersebut sukses menduduki jabatan sebagai legislatorberkat peranan dan dukungan

Jurnal Socius Vol. 3, No.1, Th. 2016 ISSN: 2356-4180 dominan pihak laki-laki yang ada di keluarga mereka. Diantara kerabat lakilaki yang mendukung dan membantu mereka itu ada yang berstatus datuk penghulu, sebagai kepala suku kaum. Ada juga yangmenjadi pengusaha kontraktor yang secara finansial sangat mendukung mereka untuk mendapatkan kursi di DPRD. Lalu ada juga suami yang membantu secara finansial. Bentuk dukungan datang dari mamak yang turut mengkampanyekan kepada orang sekampung untukmemberikan suara pada kemenakanannya yang menjadi Caleg. Bahkan saudara laki-laki yang menjadi politikus turut serta menyokong adiknya menjadi anggota DPRD misalnya.

\section{Penutup}

Tak dapat disangkal bahwa keberhasilan perempuan untuk duduk di parlemen sekarang ini tak lain karena mendapatkan fasilitas dan dukungan dari kaum laki-laki di sekitar mereka. Kemandirian mereka untuk mendapatkan kursi di parlemen masih perlu dipertanyakan. Ini juga berarti bahwa sistem matrilineal pada etnis Minangkabau tak sepenuhnya memberi keleluasaan bagi perempuan untuk berkiprah di sektor publik, kecuali dengan seizin dan dukungan para anggota lakilaki terdekat mereka.

Sistem matrilineal dari dulu dan sekarang di Sumatra Barat masihlah sama tipenya dengan situasi awal abad 20, dimana perempuan terkesan masih belum sepenuhnya mandiri tapi mendapat sokongan dari pihak lain, yakni laki-laki. Namun paling tidak aktifitas perempuan di publik di wilayah yang menganut sistem matrilineal ini bisa memberi inspirasi melalui ungkapan-ungkapan dalam term adat. Patut disadari bahwa bagaimanapun pengaruh sosiokultural 
Paradoks Perempuan Minang ...

untuk kebebasan Perempuan Minang, dalam hal kebebasan mendapat pendidikan, sudah boleh dikatakan berlebih dibanding kesempatan yang diperoleh perempuan dari daerah patriarkal lainnya, namun dalam sektor politik belum signifikan menunjukkan kemandirian perempuan.

\section{Daftar Pustaka}

Blackwood, Evelyn. 1995. 'Senior Women, Model Mothers, and Dutiful Wives: Managing Gender Contradiction in MinangkabauVillage.' Pp.124-155 in Bewitching Women, Pious Men, Gender and Body Politics in Southeast Asia, edited by Aihwa Ong and Michael G. Peletz. Berkeley and Los Angeles, CA: University of California Press.

Budiman, Arief, 1985, Pembagian Kerja Secara Seksual, sebuah Pembahasan Sosiologis tentang peran wanita di dalam masyarakat, Jakarta: Gramedia

Dobbin, Christine E. 1992. Kebangkatan Islam dalam ekonomi petani yang sedang berubah Sumatra Tengah, 1784-1847. Jakarta, Indonesia: INIS

De Stuers, Cora Vreede. 1960. 'Adat and Islamic Law.' Pp. 21-41 in The
Indonesian Women: Struggles and Achievements. The Hague, Netherlands: Mouton \& Co., Publishers

Fakih, Mansour, 1996 Analisa Gender dan Transformasi Sosial, Yogyakarta: Pustaka Pelajar

Fitriyanti, 2000. Roehana Koeddoes Perempuan Sumatra Barat, Jakarta: Yayasan Jurnal Perempuan

Sanday, Peggy Reeves. 2002. Women at the Center: Life in a Modern Matriarchy, Ithacca: Cornel University Press

Wieringa, Saskia.1995 Subversive Women, New Delhi, India: Raj Press,

Wieringa, Saskia. 2002. Sexual Politics in Indonesia. Basingstoke, U.K.: Palgrave Profil Anggota DPR dan DPD RI 2014-2019, Pusat Kajian Politik Departemen Ilmu Politik FISIP Universitas Indonesia 26 September 2016

--------- Sumatera darat Dalam Angka.2012, Padang: BPS 